\title{
Effect of Replacing Soybean Meal with Lupin Seed-based Meal in Chicken Diet on Performance, Carcass Value and Meat Quality
}

\author{
Pavel Suchý, Eva Straková, Ivan Herzig, Ladislav Steinhauser, Josef Vopálenský, \\ Leo Kroupa
}

Department of Nutrition, Animal Husbandry, and Animal Hygiene, Faculty of Veterinary Hygiene and Ecology, University of Veterinary and Pharmaceutical Sciences Brno

Received April 20, 2009

Accepted January 19, 2010

\begin{abstract}
The main objective of this experimental study was to determine how diets containing lupin meal affect the performance indicators, carcass value, and chemical composition of breast and thigh muscles in broiler chickens. The diets tested in experimental groups E1 and E2 differed as follows: in group E1, one third of nitrogen-containing substances (NSs) from extracted soybean meal was replaced with NSs from lupin meal; in group E2, two thirds were replaced compared to the control group. The replacement of soybean meal with lupin meal in experimental diets failed to produce any significant effect on the average live weight of chickens on Day 42 of the fattening period compared to the control group. The replacement of soybean meal with lupin meal resulted in decreased average weight of carcass and breast muscles and in decreased yield of breast muscles. Differences between the control group (C) and group E2 were significant $(P \leq$ $0.01)$. Chickens in group E2 also showed a significant increase $(P \leq 0.01)$ in the yield of the heart and stomach compared to the control group. The differences in weight and yield of thigh muscles between the control group and the experimental groups (E1 and E2) were not significantly affected. As far as chemical composition is concerned, chickens receiving the lupin-containing feed showed a significant $(P \leq 0.01)$ increase in the ash content in breast muscles. On the contrary, in thigh muscles in group E2, the ash content decreased significantly $(P \leq 0.01)$. The content of calcium showed an increasing trend in both breast and thigh muscles in both experimental groups. In contrast, the content of magnesium in chicken muscles in both experimental groups decreased. These differences were significant $(P \leq 0.01)$ only in thigh muscles. Our results show that lupin seed is a suitable substitute for NSs contained in soybean extracted meal. It is considered optimal to replace up to one third of NSs contained in soybean meal with lupin seed. Higher inclusion rate of lupin meal in diets may reduce the growth intensity of chickens, particularly the yield of breast muscles. Due to substantial inter-varietal differences, it is necessary to optimize individual nutrients, particularly amino acids when formulating lupin-containing diets.
\end{abstract}

Broiler chickens, weight and yield of organs and muscles, chemical composition of breast and thigh muscles

From a nutritional point of view, the seed of cultivars of the genus Lupinus is a proteinenriched raw material used as feed or in feeding mixtures intended for the nutrition of practically all species and categories of farm animals. For these reasons, lupin growing areas in Europe are expanding. In the Czech Republic, growing and using lupin is not as common as in the neighbouring countries. Ecologically speaking, lupins are promoted because most lupin varieties are not genetically modified.

The use of lupins in diets for poultry was tested by a number of authors, for example by Schams-Schargh et al. (1994). Their experiment examined the effect of sweet lupins in diets, particularly the variety Amiga, included at 6, 12, and 18\% inclusion rate. The authors concluded that there were no significant differences between the groups in the fattening capacity, the percentage of fat, and the percentage of valuable parts of carcass. RothMaier and Kirchgessner (1994) who tested diets containing up to $45 \%$ of white lupin arrived at the conclusion that the supplementation of a diet with up to $20 \%$ of white lupin had no adverse effects on the performance of broilers. Similar findings were reported by Lettner

Address for correspondence:

Prof. MVDr. Ing. Pavel Suchý, CSc.

University of Veterinary and Pharmaceutical Sciences, Brno

Faculty of Veterinary Hygiene and Ecology

Department of Nutrition, Animal Husbandry, and Animal Hygiene

Palackého 1/3, 61242 Brno, Czech Republic

Tel. +420541562670

Fax +420541562 675

E-mail: suchyp@vfu.cz

http://www.vfu.cz/acta-vet/actavet.htm 
and Zollitsch (1995), Sitko and Čermák (1998) or Teixeira and Dos (1995), showing that the performance indicators, carcass value and meat quality, including average daily gain, protein deposition in a carcass and energy retention did not differ between individual groups when lupin meal was included at up to $20 \%$ of the diet administered. Egorov et al. (2001) also reported that the best results were obtained with lupin included in a diet at $20 \%$. A diet containing $25 \%$ of lupin resulted in significant decrease $(P \leq 0.05)$ of body weight. The same findings were reported by RothMaier and Paulicks (2003). If peeled or supplemented with exogenic enzymes, the nutritional value of lupin seed increases, as reported by Rubio et al. (2003) and Mieczkowska and Smulikowska (2005), respectively. The positive effect of enzymes in lupin-meal-containg diets on the utilization of lupin saccharides in broiler diets is emphasized by many authors, for example by Kocher et al. (2000), Hughes et al. (2000), Brenes et al. (2002), Brenes et al. (2003), Steenfeldt et al. (2003), and Mieczkowska et al. (2004).

Apart from specific saccharides, particularly alkaloids are considered to be the antinutritional substances of lupins. Unlike wild varieties of lupin, the content of alkaloids in cultural lupin varieties is very low. However, it is important to address this issue in cultural varieties, as reported by Francesch et al. (1990), Uzieblo et al. (1996), Bednarczyk et al. (1996) and Olkowski et al. (2001).

This paper extends our current knowledge on lupin seeds and helps to promote its use as an important source of proteins in diets intended for the feeding of broiler chickens. Its main advantage lies particularly in the scope and complexity of the solution, extending from animal nutrition to the quality of the product. The use of the seed of Lupinus cultivars contributes to the use of alternative sources of protein feeds in the nutrition of farm animals. This is an intensively studied topic, as documented by the conclusions of the global meeting Lupins for Health and Wealth, $12^{\text {th }}$ International Lupin Conference, held 14-18 September 2008 in Fremantle, Western Australia.

\section{Materials and Methods}

This study was designed to verify to what extent extracted soybean meal can be replaced with lupin seed meal (Lupinus) in diets intended for fattening broiler chickens, and to investigate the effect of this component on performance, carcass value and chemical composition of chicken muscles. The experiment used the variety Amiga from a group of white flowering lupins.

The experiment was performed in an accredited experimental livestock stable at the Department of Nutrition, Animal Husbandry, and Animal Hygiene, University of Veterinary and Pharmaceutical Sciences Brno.

There were 3 groups of Ross 308 sexed chickens, control group C ( 35 females and 35 males), experimental groups E1 ( 35 females and 35 males) and E2 ( 35 females and 35 males). Chickens were fed according to the standard operating procedure for the fattening of Ross 308 broiler chickens. Unlike the control group, the experimental feeding mixtures contained lupin meal that replaced one third or two thirds of nitrogen-containing substances (NSs) of extracted soybean meal (E1 and E2). In order to meet the amino acid requirements, the diets with lupin meal were supplemented with synthetic amino acids L-lysine, L-threonine and D, L-methionine. Components contained in feeding mixtures are listed in Table 1. In the course of the experiment, chickens were weighed on Days 1, 15, 30 and 42. On Day 42 chickens were slaughtered and 20 chickens (10 females and 10 males) from each group were subjected to slaughter analyses and chemical analysis of meat. Chickens for analysis were selected according to the mean weight of chickens in a particular group.

The weight of carcass (WCar), the weight of the neck (WNe), the weight of the heart (WHe), the weight of the liver (WLi), the weight of the stomach (WSt), the weight of abdominal fat (WAF), the weight of breast muscles (WBM), the weight of the unskinned right and left thigh (WUT), the weight of the skinned right and left thigh (WST) (HSbK), and the weight of thigh muscles on both thighs (WTT) (HSS) were determined for each chicken. The results obtained were used to calculate the yield of carcass, organs and tissues in relation to the live weight of the chickens. Muscles (breast, thighs) obtained from the carcass analysis were subjected to chemical analysis. Crude protein was determined in muscles $(\mathrm{N} \times 6.25)$. Nitrogen was determined according to the Kjeldahl method using the Buchi analyser (Centec automatika, spol. s.r.o.). The content of crude fat was determined using ANKOM ${ }^{\mathrm{XT10}}$ Fat Analyzer (O.K. SERVIS BioPro). The content of ash was determined gravimetrically after incineration at a temperature of $550{ }^{\circ} \mathrm{C}$ at pre-defined conditions. The contents of calcium, phosphorus and magnesium were determined after the incineration of a sample of meat. Calcium and magnesium were determined in a chloride extract using chelatometry (chelaton 3 - di - NA EDTA), while phosphorus was 
Table 1. Composition of feeding mixtures and the period of their administration during the fattening period in individual experimental groups

\begin{tabular}{|l|c|c|c|c|c|c|c|c|c|}
\hline \multirow{2}{*}{\begin{tabular}{c} 
Components \\
\multicolumn{1}{c|}{$(\mathrm{kg})$}
\end{tabular}} & \multicolumn{3}{|c|}{$\begin{array}{c}\text { BR 1 } \\
\text { (Day 1-15) }\end{array}$} & \multicolumn{3}{c|}{$\begin{array}{c}\text { BR 2 } \\
\text { (Day 16-30) }\end{array}$} & \multicolumn{3}{c|}{$\begin{array}{c}\text { BR 3 } \\
\text { (Day 30-42) }\end{array}$} \\
\cline { 2 - 11 } & $\mathrm{C}$ & E1 & E2 & C & E1 & E2 & C & E1 & E2 \\
\hline Wheat & 41.20 & 37.21 & 34.03 & 47.73 & 44.53 & 41.54 & 47.92 & 49.80 & 47.77 \\
\hline Maize & 15.00 & 15.00 & 15.00 & 15.00 & 15.00 & 15.00 & 20.00 & 20.00 & 20.00 \\
\hline Soybean extr. meal & 35.80 & 23.87 & 11.23 & 29.60 & 19.73 & 9.87 & 24.00 & 13.33 & 6.66 \\
\hline Lupin & 0.00 & 15.51 & 31.03 & 0.00 & 12.83 & 25.65 & 0.00 & 8.67 & 17.33 \\
\hline D,L-Met 100\% & 0.30 & 0.40 & 0.50 & 0.25 & 0.35 & 0.39 & 0.20 & 0.25 & 0.28 \\
\hline L-Lys & 0.30 & 0.50 & 0.70 & 0.23 & 0.29 & 0.32 & 0.12 & 0.17 & 0.18 \\
\hline L-Thr & 0.12 & 0.22 & 0.22 & 0.08 & 1.12 & 0.12 & 0.05 & 0.07 & 0.07 \\
\hline MCP* & 1.18 & 1.18 & 1.18 & 1.00 & 1.00 & 1.00 & 0.90 & 0.90 & 0.90 \\
\hline NaCl & 0.38 & 0.38 & 0.38 & 0.38 & 0.38 & 0.38 & 0.36 & 0.36 & 0.36 \\
\hline Limestone, ground & 1.62 & 1.63 & 1.63 & 1.63 & 1.63 & 1.63 & 1.55 & 1.55 & 1.55 \\
\hline Soya oil & 3.60 & 3.60 & 3.60 & 3.60 & 3.60 & 3.60 & 4.10 & 1.40 & 4.40 \\
\hline Premix Mikrop** & 0.50 & 0.50 & 0.50 & 0.50 & 0.50 & 0.50 & 0.50 & 0.50 & 0.50 \\
\hline
\end{tabular}

*Monocalcium phosphate

** The premix of specifically active substances used by the producer contained: vitamin A 1600000 IU; vitamin D3 $500000 \mathrm{IU}$; alpha-tocopherol $10000 \mathrm{mg}$; vitamin K3 $300 \mathrm{mg}$; vitamin B1 $800 \mathrm{mg}$; vitamin B2 1300 $\mathrm{mg}$; vitamin B6 $600 \mathrm{mg}$; vitamin B12 $3 \mathrm{mg}$; biotin $30 \mathrm{mg}$; folic acid $500 \mathrm{mg}$; niacinamide $6000 \mathrm{mg}$; calcium pantothenate $2500 \mathrm{mg}$; betaine $50000 \mathrm{mg}$; butylhydroxytoluene $3400 \mathrm{mg}$; propyl gallate $1200 \mathrm{mg}$; ethoxyquin $540 \mathrm{mg}$; ferrous sulphate monohydrate $10000 \mathrm{mg}$; manganese oxide $16000 \mathrm{mg}$; zinc oxide $16000 \mathrm{mg}$; copper sulphate $1700 \mathrm{mg}$; potassium iodide $200 \mathrm{mg}$; sodium selenite $30 \mathrm{mg}$; cobalt sulphate $50 \mathrm{mg}$; phytase $50000 \mathrm{FTU}$; glucanase $24000 \mathrm{BGU}$; xylanase $1100000 \mathrm{EXU}$

determined photometrically at $445 \mathrm{~nm}$. The gross energy of muscles was determined calorimetrically using AC 500 (LECO). The chemical values of muscles presented in this paper are expressed per $100 \%$ dry matter.

The results obtained were processed by the statistical programme Unistat $\mathrm{CZ}$ version 5.6 for Excel which evaluated the mean values and their differences by multiple comparisons using the Tukey-HSD test, at significance levels of $P \leq 0.01$ and $P \leq 0.05$.

\section{Results and Discussion}

The performance indicators determined show that extracted soybean meal in diets used for the fattening of broiler chickens can be replaced with lupin-seed meal without significantly affecting the live weight of chickens during fattening (Fig.1). Fig.1 shows that live weight in groups E1 and E2 decreased slightly (non-significantly) at the end of the fattening period. Both experimental groups E1 and E2 also exhibited lower feed conversion $(1.82 \mathrm{~kg}$ and $1.87 \mathrm{~kg}$ ) compared to the control chickens $(1.70 \mathrm{~kg})$. The results are in agreement with the findings of RothMaier and Kirchgessner (1994) or Schams-Schargh et al. (1994) who reported that lupin included in a diet up to $20 \%$ did not significantly affect the performance indicators of fattened chickens. It is apparent that the lower content of amino acids in feeding mixtures in the experimental groups of chickens in the last phase of the fattening period, i.e. from Day 30, was associated with a reduction in the average live weight and the lowered conversion of feeding mixtures (Table 2). When evaluating the carcass value, we arrived at the conclusion that in the experimental group with the highest inclusion rate of lupin meal (E2) the substitution manifested itself negatively by a significant $(P \leq 0.01)$ decrease in carcass weight compared to control, and by a significant $(P \leq 0.01)$ decrease in the weight of breast muscles in both experimental groups, as documented in Table 3. The results show that when two thirds of NSs from soybean meal were replaced with lupin meal in group E2, it had a suppressing effect on growth intensity, particularly 


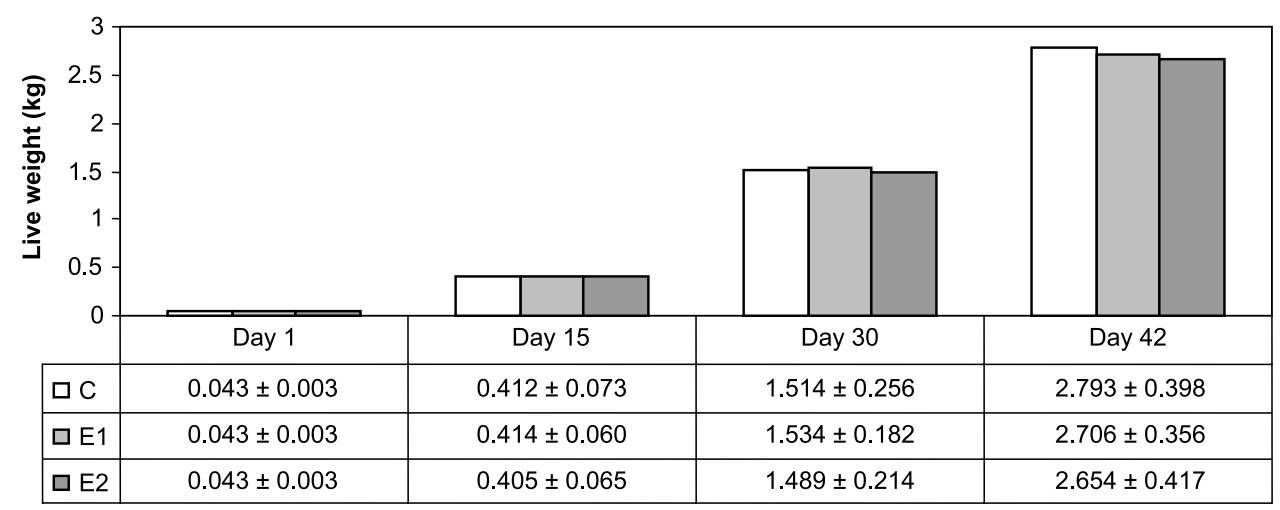

Fig. 1. Variation in the live weight of chickens $(\mathrm{kg})$ during the experimental period $(\mathrm{C}$ is the control group, E1 and $\mathrm{E} 2$ are experimental groups) $(\mathrm{x} \pm \mathrm{SD})$

on the development of breast muscles. This conclusion is corroborated by a significant $(P \leq 0.01)$ difference in the yield of breast muscles between control chickens and experimental chickens in group E2. When the values are expressed as percentage (Table 3), the diet with the highest inclusion rate of lupin meal (group E2) resulted in a significant increase $(P \leq 0.01)$ in the yield of the heart and stomach compared to control chickens. We assume that these differences are associated with the increased consumption (lower conversion) of feeding mixtures and the increased load of metabolism in experimental chickens in group E2. The results of our study indicate that higher inclusion rate of lupin meal in a diet may have a negative effect on some

Table 2. The contents of crude protein, metabolizable energy (ME) and amino acids in feeding mixtures used in individual experimental groups

\begin{tabular}{|l|c|c|c|c|c|c|c|c|c|}
\hline \multirow{2}{*}{$\begin{array}{c}\text { Components } \\
(\mathrm{kg})\end{array}$} & \multicolumn{3}{|c|}{$\begin{array}{c}\text { BR 1 } \\
\text { (Day 1-15) }\end{array}$} & \multicolumn{3}{c|}{$\begin{array}{c}\text { BR 2 } \\
\text { (Day 16-30) }\end{array}$} & \multicolumn{3}{c|}{$\begin{array}{c}\text { BR 3 } \\
\text { (Day 30-42) }\end{array}$} \\
\cline { 2 - 12 } & C & E1 & E2 & C & E1 & E2 & C & E1 & E2 \\
\hline Crude protein & 238.9 & 234.2 & 225.4 & 219.7 & 213.3 & 207.8 & 189.3 & 170.5 & 161.6 \\
\hline ME (MJ/kg) & 12.1 & 12.0 & 12.0 & 12.0 & 12.2 & 12.2 & 12.7 & 12.9 & 13.0 \\
\hline Asp & 24.0 & 20.7 & 20.0 & 19.3 & 19.7 & 17.8 & 15.8 & 13.8 & 12.5 \\
\hline Thr & 9.3 & 8.7 & 8.6 & 7.6 & 8.0 & 7.4 & 7.6 & 6.7 & 6.0 \\
\hline Ser & 11.1 & 9.8 & 9.9 & 9.7 & 9.7 & 9.2 & 8.8 & 7.8 & 7.4 \\
\hline Glu & 42.7 & 41.6 & 41.5 & 41.1 & 41.9 & 40.7 & 39.6 & 36.8 & 32.7 \\
\hline Pro & 13.4 & 12.4 & 11.1 & 12.9 & 12.5 & 11.3 & 12.8 & 12.9 & 8.8 \\
\hline Gly & 9.5 & 8.6 & 8.4 & 8.4 & 8.6 & 7.9 & 5.4 & 4.8 & 6.5 \\
\hline Ala & 9.6 & 8.2 & 7.7 & 8.3 & 8.2 & 7.1 & 7.1 & 5.9 & 6.6 \\
\hline Val & 10.9 & 9.4 & 8.3 & 8.6 & 8.5 & 7.5 & 8.0 & 7.1 & 6.7 \\
\hline Met & 4.9 & 4.4 & 3.3 & 5.0 & 4.9 & 6.0 & 4.2 & 4.0 & 5.3 \\
\hline Ileu & 10.0 & 9.3 & 8.6 & 8.5 & 8.7 & 7.9 & 6.5 & 5.6 & 6.1 \\
\hline Leu & 17.8 & 16.6 & 16.0 & 15.6 & 15.9 & 14.6 & 12.9 & 11.2 & 11.9 \\
\hline Tyr & 7.0 & 6.8 & 7.0 & 6.1 & 6.7 & 7.3 & 4.8 & 4.6 & 5.5 \\
\hline Phe & 11.5 & 9.9 & 9.2 & 10.2 & 9.6 & 8.8 & 8.4 & 7.1 & 7.2 \\
\hline His & 6.3 & 5.5 & 5.3 & 5.7 & 5.6 & 5.1 & 4.6 & 3.5 & 4.0 \\
\hline Lys & 14.3 & 13.8 & 14.2 & 11.3 & 11.7 & 10.4 & 8.8 & 7.6 & 8.6 \\
\hline Arg & 18.4 & 19.2 & 20.7 & 15.0 & 16.9 & 18.1 & 12.2 & 11.9 & 13.7 \\
\hline
\end{tabular}


Table 3. Carcass values of broiler chickens on Day 42

\begin{tabular}{|c|c|c|c|c|c|c|c|}
\hline $\begin{array}{c}\text { Indicator } \\
(\mathrm{g})\end{array}$ & $\begin{array}{c}\text { Control } \\
\mathrm{C}\end{array}$ & $\begin{array}{c}\text { Experimental } \\
\text { E1 }\end{array}$ & $\begin{array}{c}\text { Experimental } \\
\text { E2 }\end{array}$ & $\begin{array}{c}\text { Indicator } \\
(\%)\end{array}$ & $\begin{array}{c}\text { Control } \\
\mathrm{C}\end{array}$ & $\begin{array}{c}\text { Experimental } \\
\text { E1 }\end{array}$ & $\begin{array}{c}\text { Experimental } \\
\text { E2 }\end{array}$ \\
\hline \multirow{2}{*}{ WCar } & $2090.85^{\mathrm{A}}$ & 1997.70 & $1924.05^{\mathrm{B}}$ & YCar & 73.69 & 71.22 & 70.99 \\
& \pm 183.30 & \pm 191.22 & \pm 193.29 & & \pm 8.84 & \pm 1.46 & \pm 2.61 \\
\hline \multirow{2}{*}{ WNe } & 81.35 & 79.75 & 78,64 & YNe & 2.856 & 2.85 & 2.90 \\
& \pm 11.56 & \pm 11.32 & \pm 11.96 & & \pm 0.38 & \pm 0.32 & \pm 0.32 \\
\hline \multirow{2}{*}{ WHe } & 15.61 & 16.205 & 16.66 & YHe & $0.55^{\mathrm{A}}$ & 0.57 & $0.62^{\mathrm{B}}$ \\
& \pm 2.26 & \pm 3.38 & \pm 2.95 & & \pm 0.07 & \pm 0.07 & \pm 0.10 \\
\hline \multirow{2}{*}{ WLi } & 46.87 & 44.11 & 43.520 & YLi & 1.65 & 1.57 & 1.61 \\
& \pm 7.56 & \pm 8.72 & \pm 8.24 & & \pm 0.28 & \pm 0.25 & \pm 0.27 \\
\hline \multirow{2}{*}{ WSt } & 42.48 & 44.74 & 48.06 & YSt & $1.50^{\mathrm{A}}$ & 1.60 & $1.79^{\mathrm{B}}$ \\
& \pm 8.42 & \pm 5.68 & \pm 10.09 & & \pm 0.33 & \pm 0.23 & \pm 0.40 \\
\hline \multirow{2}{*}{ WAF } & 34.86 & 36.84 & 43.83 & YAF & 1.24 & 1.34 & 1.63 \\
& \pm 10.50 & \pm 16.50 & \pm 15.00 & & \pm 0.40 & \pm 0.67 & \pm 0.57 \\
\hline \multirow{2}{*}{ WBM } & $571.87^{\mathrm{A}}$ & $490.77^{\mathrm{B}}$ & $438.73^{\mathrm{C}}$ & YBM & $20.16^{\mathrm{A}}$ & 17.55 & $16.30^{\mathrm{B}}$ \\
& \pm 62.17 & \pm 61.58 & \pm 44.45 & & \pm 2.64 & \pm 2.08 & \pm 1.99 \\
\hline \multirow{2}{*}{ WUT } & 602.06 & 577.51 & 568.09 & YUT & 21.24 & 20.55 & 21.01 \\
& \pm 70.21 & \pm 83.40 & \pm 68.50 & & \pm 3.27 & \pm 1.81 & \pm 2.07 \\
\hline \multirow{2}{*}{ WST } & 519.03 & 509.09 & 501.27 & YST & 18.27 & 18.07 & 18.52 \\
& \pm 69.80 & \pm 80.50 & \pm 58.68 & & \pm 2.77 & \pm 1.51 & \pm 1.57 \\
\hline \multirow{2}{*}{ WTT } & 51.78 & 64.10 & 54.605 & YTT & 13.60 & 13.04 & 13.24 \\
& \pm 11.58 & \pm 14.33 & \pm 12.21 & & \pm 2.02 & \pm 1.68 & \pm 1.90 \\
\hline
\end{tabular}

${ }_{\mathrm{A}, \mathrm{B}, \mathrm{C}}$ The mean values with different superscripts in the same indicators differ significantly $(P \leq 0.01)$

$\mathrm{W}$ - weight, $\mathrm{Y}$ - yield, Car - carcass, $\mathrm{Ne}$ - neck, $\mathrm{He}$ - heart, $\mathrm{Li}$ - liver, $\mathrm{St}$ - stomach, $\mathrm{AF}$ - abdominal fat, $\mathrm{BM}$ breast muscles, UT - unskinned thighs, ST - skinned thighs, TT - thigh muscles on both thighs

performance indicators and carcass value, as shown in experimental chickens in group E2. The results are in agreement with the findings reported by Egorov et al. (2001), who found that the best results were obtained with lupin included in a diet at $20 \%$. Twenty-five \% of lupin in a diet resulted in a significant $(P \leq 0.05)$ decrease in body weight, i.e. growth suppression. Similar studies with the same conclusions were also conducted by RothMaier and Paulicks (2003).

The nutritional value based on the chemical composition of foodstuffs is one of the major indicators in defining the quality of food. One part of the experimental work was therefore to determine whether the administered diets would affect the chemical composition of breast and thigh muscles, which are an important part of human nutrition. The results of the chemical analysis of breast and thigh muscles composition (per 100\% dry matter) are provided in Table 4 . These results of chemical analyses show that no significant differences in the average content of basic organic substances (crude protein and crude fat) were observed among the groups (Table 4). The results show that the substitution of soybean meal with lupin meal did not affect the above-mentioned indicators of meat quality. Differences were confirmed only for minerals, as assessed on the basis of ash content. Breast muscles showed a significant increase $(P \leq 0.01)$ in the ash content in experimental chickens in both groups E1 and E2 compared to control chickens. This increase was accompanied with a non-significant increase in the content of calcium and phosphorus and a decrease in the content of magnesium. A different trend was observed in thigh muscles, with a highly significant $(P \leq 0.01)$ decrease detected in the ash content in group E2 that received the diet with the highest inclusion of lupin (Table 4). This decrease in the ash content in thigh muscles corresponded to 
Table 4. Chemical composition of breast and thigh muscles in broiler chickens on Day 42 of the fattening period in $100 \%$ dry matter

\begin{tabular}{|c|c|c|c|c|c|c|c|}
\hline \multirow{2}{*}{ Indicator } & \multirow{2}{*}{ Unit } & \multicolumn{3}{|c|}{ Breast muscle } & \multicolumn{3}{|c|}{ Thigh muscle } \\
\hline & & $\mathrm{C}$ & E1 & E2 & $\mathrm{C}$ & E1 & E2 \\
\hline \multirow{2}{*}{ Crude protein } & \multirow{2}{*}{$\mathrm{g} / \mathrm{kg}$} & 877.59 & 874.39 & 877.08 & 656.94 & 648.78 & 651.62 \\
\hline & & \pm 22.43 & \pm 34.50 & \pm 16.32 & \pm 99.86 & \pm 41.08 & \pm 48.56 \\
\hline \multirow{2}{*}{ Crude fat } & \multirow{2}{*}{$\mathrm{g} / \mathrm{kg}$} & 72.75 & 59.66 & 68.685 & 278.33 & 277.93 & 300.79 \\
\hline & & \pm 19.54 & \pm 17.43 & \pm 15.19 & \pm 48.90 & \pm 40.76 & \pm 37.76 \\
\hline \multirow{2}{*}{ Ash } & \multirow{2}{*}{$\mathrm{g} / \mathrm{kg}$} & $46.39^{\mathrm{A}}$ & $48.58^{\mathrm{B}}$ & $48.67^{\mathrm{B}}$ & $40.62^{\mathrm{A}}$ & $40.73^{\mathrm{A}}$ & $38.16^{\mathrm{B}}$ \\
\hline & & \pm 1.39 & \pm 1.51 & \pm 1.61 & \pm 3.01 & \pm 2.59 & \pm 1.97 \\
\hline \multirow{2}{*}{ Calcium } & \multirow{2}{*}{$\mathrm{g} / \mathrm{kg}$} & 2.02 & 2.13 & 2.13 & $1.61^{\mathrm{A}}$ & $1.80^{\mathrm{B}}$ & $1.81^{\mathrm{B}}$ \\
\hline & & \pm 0.22 & \pm 0.12 & \pm 0.13 & \pm 0.20 & \pm 0.15 & \pm 0.11 \\
\hline \multirow{2}{*}{ Phosphorus } & \multirow{2}{*}{$\mathrm{g} / \mathrm{kg}$} & 9.22 & 9.46 & 9.48 & 7.50 & 7.27 & 7.49 \\
\hline & & \pm 0.28 & \pm 0.31 & \pm 0.62 & \pm 0.40 & \pm 0.30 & \pm 0.45 \\
\hline \multirow{2}{*}{ Magnesium } & \multirow{2}{*}{$\mathrm{g} / \mathrm{kg}$} & 1.48 & 1.40 & 1.39 & $1.23^{\mathrm{A}}$ & $1.13^{\mathrm{B}}$ & $1.01^{\mathrm{C}}$ \\
\hline & & \pm 0.13 & \pm 0.17 & \pm 0.19 & \pm 0.17 & \pm 0.11 & \pm 0.09 \\
\hline \multirow{2}{*}{ Gross energy } & \multirow{2}{*}{$\mathrm{MJ} / \mathrm{kg}$} & 23.58 & 23.34 & 23.42 & 26.84 & 26.99 & 27.23 \\
\hline & & \pm 0.40 & \pm 0.32 & \pm 0.32 & \pm 0.83 & \pm 0.65 & \pm 0.67 \\
\hline
\end{tabular}

$\mathrm{A}, \mathrm{B}, \mathrm{C}$ The mean values with different superscripts in the same indicator differ significantly $(P \leq 0.01)$

a significant $(P \leq 0.01)$ decrease in the content of magnesium in group E2 compared to controls and group E2. Similar to breast muscles, calcium content in thigh muscles also increased in both experimental groups E1 and E2. Unlike breast muscles, in thigh muscles these differences were significant $(P \leq 0.01)$. When evaluating gross energy based on the results, we concluded that the diet did not have a significant effect on the energy value in both breast and thigh muscles. Our results are in agreement with those reported by Lettner and Zollitsch (1995), Sitko and Čermák (1998) and Teixeira and Dos (1995) who showed that performance indicators, carcass values, and meat quality (including average daily gain, protein deposition in a carcass and energy retention) did not differ between the groups when the administered diet contained $20 \%$ of lupin meal. However, these authors did not study the contents of minerals in muscles of fattened chickens in as much detail as we did.

Our results show that the substitution of extracted soybean meal in diets influenced the carcass value and chemical composition of meat in fattened chickens. The effect of the higher content of lupin meal in a diet was manifested by reduced weight and yield in experimental chickens at the end of the fattening period. Carcass characteristics were also affected as the weight of breast muscles and the respective yield of breast muscles decreased. Such changes in experimental groups were accompanied with increased yield of stomach and heart in group E2 that received a diet where two thirds of NSs contained in extracted soybean meal were replaced with NSs from lupin seeds. The chemical composition of muscles in experimental groups revealed that the ash content increased in breast muscles and decreased in thigh muscles. According to the analysis of elements, the content of calcium in breast and thigh muscles increased while the content of magnesium decreased with the substitution of soybean meal with lupin. In conclusion, lupin seed is a suitable substitute for nitrogen-containing substances in extracted soybean meal. In order to obtain the optimum results, the inclusion rate should not exceed one third of NSs in soybean meal. If the inclusion rate of lupin meal in a diet is higher, the growth intensity in chickens, particularly the yield of breast muscles, may decrease. When formulating a diet containing lupin, it is necessary to optimize the contents of individual nutrients, particularly amino acids. 


\section{Náhrada sojového šrotu $v$ dietě šrotem $z$ lupinových semen a jeho vliv na užitkovost, jateční hodnotu a kvalitu masa kuřat}

Cílem experimentální práce bylo zjistit, jak diety s obsahem lupinového šrotu ovlivní užitkovost, jateční hodnotu a chemické složení prsní a stehenní svaloviny brojlerových kuřat. Diety se lišily tím, že u experimentální skupiny E1 byla 1/3 dusíkatých látek (NL) sojového extrahovaného šrotu nahrazena NL z lupinového šrotu a u skupiny E2 byla provedena náhrada $2 / 3$ NL oproti kontrole. Náhrada sojového šrotu lupinovým šrotem v experimentálních dietách neovlivnila ve 42. dnu výkrmu průměrnou živou hmotnost kuřat ve srovnání $\mathrm{s}$ kontrolou. Náhrada sojového šrotu lupinovým snížila průměrnou hmotnost jatečně opracovaného těla, průměrnou hmotnost prsní svaloviny a výtěžnost prsní svaloviny. Jako vysoce významné $(P \leq 0.01)$ byly tyto rozdíly testovány především mezi kontrolou a skupinou E2. U kuřat pokusné skupiny E2, oproti kontrole, bylo zaznamenáno i vysoce významné $(P \leq 0.01)$ zvýšení výtěžnosti srdce a žaludku. Rozdíly v hmotnosti a výtěžnosti stehenní svaloviny mezi kontrolní a pokusnými skupinami (E1 a E2), statisticky významně ovlivněny nebyly. V chemickém složení svaloviny u pokusných kuřat, kterým byly podávány diety s obsahem lupiny, bylo prokázáno vysoce významné $(P \leq 0.01)$ zvýšení obsahu popelovin v prsní svalovině. U popelovin stehenní svaloviny, u skupiny E2, bylo naopak prokázáno jejich vysoce signifikantní $(P \leq 0.01)$ snížení. U obsahu vápníku byla pozorována tendence jeho zvyšování v prsní i stehenní svalovině u kuřat pokusných skupin. Naopak u obsahu hořčíku ve svalovině pokusných kuřat byla zaznamenána tendence jeho poklesu. Jako vysoce významné $(P \leq 0.01)$ byly uvedené rozdíly testovány pouze u stehenní svaloviny. $Z$ dosažených výsledků studie lze konstatovat, že lupinová semena jsou vhodnou náhradou NL za sojový extrahovaný šrot. Za optimální náhradu lze považovat náhradu do 1/3 NL sojového šrotu. Vyšší podíl lupinového šrotu v dietách může vést ke snížení růstové intenzity kuřat, především růstu prsní svaloviny. Při sestavování diet s obsahem lupiny je nutné, vzhledem k vysoké odrůdové rozdílnosti, optimalizovat jednotlivé živiny v dietě, především se zaměřením na jednotlivé aminokyseliny.

\section{Acknowledgement}

This study was part of the grant project of the Ministry of Agriculture of the Czech Republic, NAZV No. QG 60142 .

\section{References}

Bednarczyk M, Lisowski M, Siwek M, Uziębło L, Stobiecki M, Gulewicz K 1996: Estimation of influence of different groups of chemical compounds from Lupinus angustifolius seeds on development of chicken embryo. Bull Polish Acad Sci-Chem 44: 71-83

Brenes A, Slominski BA, Marquardt RR, Guenter W, Viveros A 2003: Effect of enzyme addition on the digestibilities of cell wall polysaccharides and oligosaccharides from whole, dehulled, and ethanol-extracted white lupins in chickens. Poult Sci 82: 1716-1725

Brenes A, Marquardt RR, Guenter W, Viveros A 2002: Effect of enzyme addition on the performance and gastrointestinal tract size of chicks fed lupin seed and their fractions. Poult Sci 81: 670-678

Egorov IA, Chesnokova NY, Takunov IP 2001: Feed value of lupin for broiler chickens and laying hens. Kormoproizvodstvo 1: $28-30$

Francesch M, Perez-Vendrell A, Esteve E, Brufau J 1990: Use of white lupin (Lupinus albus) and blue lupin (Lupinus angustifolius) with intermediate or high alkaloid content in feeding broiler chickens. Invest Agr: Prod Sanidad Anim 5: 91-107

Hughes RJ, Choct M, Kocher A, Van Barneveld RJ 2000: Effect of food enzymes on AME and composition of digesta from broiler chickens fed on diets containing non-starch polysaccharides isolated from lupin kernel. Br Poult Sci 41: 318-323

Kocher A, Choct M, Hughes RJ, Broz J 2000: Effect of food enzymes on utilisation of lupin carbohydrates by broilers. Br Poult Sci 41: 75-82

Lettner F, Zollitsch W 1995: Lupins in broiler feeds. Forderungsdienst 43: 285-288

Mieczkowska A, Smulikowska S 2005: The influence of white lupin seeds in diets supplemented with fats of animal or plant origin on the fatty acid composition of broiler tissues. J Anim Feed Sci 14: 93-107 
Mieczkowska A, Smulikowska S, Nguyen CV 2004: Effect of enzyme supplementation of white lupin (Lupinus albus var. Butan)-containing diets on performance, nutrient digestibility, viscosity, $\mathrm{pH}$, and passage rate of digesta in broiler chickens. J Anim Feed Sci 13: 475-486

Olkowski AA, Olkowski BI, Amarowicz R, Classen HL 2001: Adverse effects of dietary lupine in broiler chickens. Poult Sci 80: 621-625

RothMaier DA, Paulicks BR 2003: Feeding and nutritional value of sweet blue and yellow lupin seed (Lupinus angustifolius L., Lupinus luteus L.) for broiler chicks. Arch Geflügelkd 67: 175-178

RothMaier DA, Kirchgessner M 1994: White lupins (Lupinus albus, L) as a replacement for soybean meal in diets for fattening chickens. Arch Geflügelkd 58: 111-114

Rubio LA, Brenes A, Centeno C 2003: Effects of feeding growing broiler chickens with practical diets containing sweet lupin (Lupinus angustifolius) seed meal. Br Poult Sci 44: 391-397

Schams-Schargh M, Zollitsch W, Knaus W, Lettner F 1994: Der Einsatz von Lupinen in der Hühnerfütterung. Bodenkultur 45: 163-175

Sitko VA, Čermák B 1998: Influence of lupin seed on performance and meat quality of broilers. Sborník Zemědělské Fakulty Jihočeské Univerzity, České Budějovice: Zootechnická řada 15: 3-9

Steenfeldt S, González E, Bach Knudsen KE 2003: Effects of inclusion with blue lupins (Lupinus angustifolius) in broiler diets and enzyme supplementation on production performance, digestibility and dietary AME content. Anim Feed Sci Technol 110: 185-200

Teixeira AS, Dos R 1995: Replacement of soyabeans by lupins (Lupinus luteus) in the feeding of broiler fowls. Rev Portug Ciênc Veter 90: 20-28

Uziębło L, Gulewicz K, Tarasewicz Z, Bednarczyk M, Szczerbińska D, Ligocki M 1996: Effect of lupin alkaloid fraction level on performance and blood parameters in chickens. J Anim Feed Sci 5: 261-271 